\title{
Correlation Between Product Placement in Films, Purchase INTENTION AND BRAND ATTITUDE
}

\author{
Liew Yee Shan \\ UCSI University \\ Lewyeeshan613@hotmail.com \\ Rabiah Adawiah Abu Seman \\ UCSI University \\ rabiah@ucsiuniversity.edu.my \\ Tee Jing $\mathrm{Ni}$ \\ UCSI University \\ jingnitee@gmail.com
}

\begin{abstract}
During the past 20 years, the practice of product placement as a marketing strategy has been widely extorted. Therefore, this research aims to analyse the effectiveness of product placement in films. An experimental design was employed with 40 respondents from UCSI University employing theories of the Hidden Message and the Character-Product Interaction (CPI). The correlations between product placement in film, purchase intention, and brand attitude were found significant. Brand attitude and purchase intention had increased after the exposure to product placement. Limitations were taken into account in terms of demographic, efficiency, and extensiveness. Theories of the Hidden Message and the Character-Product Interaction (CPI) are applicable to study product placements. In other words, marketers are suggested to use product placement strategy in films to generate positive brand attitude and sales.
\end{abstract}

Keywords: Product placement, purchase intention, brand attitude, the Hidden Message, the Character-Product Interaction (CPI), Malaysia

\section{INTRODUCTION}

"Product placement is the practice in which firms pay to place branded products (e.g., brand name/logo, package, signage, other trademarks) in the content of mass media programming" (Homer, 2009). Product placement is composed of an advertiser or company creating some attractive content to sell something (Falkow, 2010). The first investigation of product placement was in the late 1980s, in which product placement was initially defined by Steortz 
as the branded products, or signage in a motion picture (Steortz, 1987, as cited in Newell, Salmon, \& Chang, 2006). Later, Balasubramanian suggested that product placement be inconspicuous and organised as it aims to influence audiences (Balasubramanian, 1994, as cited in Kramolis \& Drabkova, 2012).

Product placement has been widely used in the international film industry because of its efficiency, but its use in Malaysia is limited. However, product placement is getting widespread in Malaysia as compared with a few years back. According to Oxford Economics, it shows that the film and TV industries in Malaysia have a contribution of RM2,910 million in 2013 (Oxford Economics, 2013). This indicated that people in Malaysia have an interest in watching film and TV, besides that, it also indicated that it will be a great potential for marketers to place product placement in the film.

Two problems are being discussed in this research. The first problem in this research is some of the marketers placed product placement without getting sufficient information, and the second problem would be due to the lack of study on product placement in Malaysia.

The first problem was inspired due to the commercialization of this society. People nowadays are living in a commercial world in which they are exposed to advertising every day, but there is still limited knowledge and information to marketers on product placement. In 1983, product placement, in the movie Risky Business, had been described as 'risky product placement' (CBC Radio, 2015). The product, Ray-Ban Wayfarers, almost plummeted in sales, but they decided to use it in the film anyway. In the end, it did bring the company back to life. This shows the risk between success and the failure of product placement.

The second problem was being discussed because of the lack of being studied in Malaysia. However, this perhaps is good news because it means that people seldom notice they have been used to watch a product placement in the film which led to the lack of attention of product placement. At first glance, it may seem like many people think that commercial advertising is the only way to place an advertisement but it is not. There are alternative avenues to product placement that can be explored.

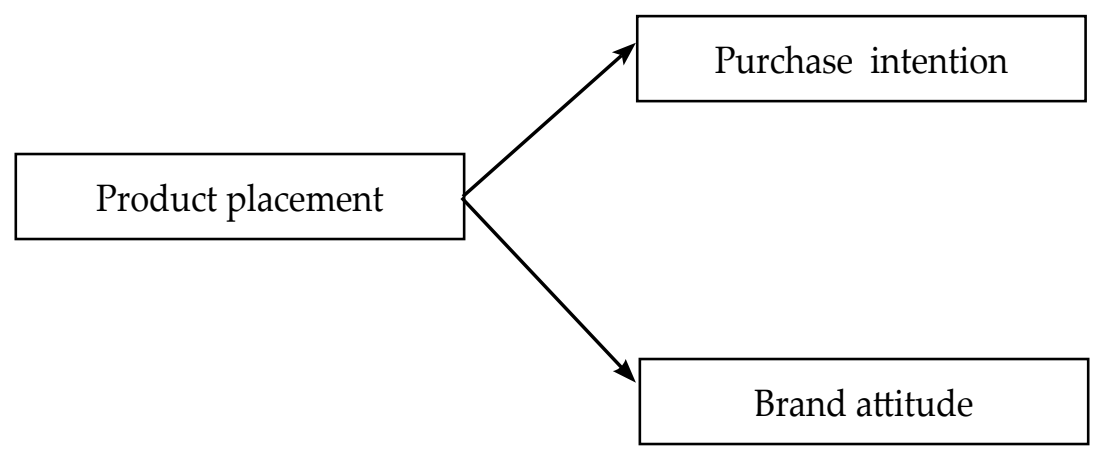

\section{Figure 1: Conceptual Framework of The Correlation of Product Placement Towards Purchase Intention and Brand Attitude}

Two theories may explain the correlation of product placement, purchase intention, and brand attitude. The two theories which guided this research are; the Hidden Message, and the Character-Product Interaction (CPI) theory. First, the Hidden Message is used when a particular message has to be manipulated or misled unconsciously to have a different point 
of view of viewers towards something (Bhasin, 2017). This theory has often been used in advertising, it changes viewers' perception by reducing, or deluding. Second, the CharacterProduct Interaction (CPI) is defined as any physical interaction of the product and character in the film (Patton, 2014). CPI is a persuasive type of placement that can be used to measure the effectiveness, awareness, attitude, purchase intention, and willingness to pay (WTP) of a consumer (Kamleitner \& Khair Jyote, 2013). CPI mainly happens in the visual type of product placement since it refers to physical interaction in film. Figure 1 shows the conceptual framework for the current study.

This study is to identify the effectiveness of product placement in the film. The objectives are as follows:

- To identify the correlation between product placement in film and purchase intention.

- To investigate the effectiveness of product placement towards brand attitude.

- To investigate the difference in purchase intention after the exposure of product placement.

- To investigate the difference in brand attitude after the exposure of product placement.

\section{LITERATURE REVIEW}

Product placement will affect purchase intention (Yao \& Huang, 2017). 84\% of respondents have higher purchase intention as a result of watching movies that have product placement (Filieri \& McLeay, 2014). Product placement intends to affect audiences' attitudes (Russell, 2002, as cited in Gillespie, Joireman, \& Muehling, 2012). Boerman, Van Reijmersdal, and Neijens (2015) conducted a research which shows that different kind of the disclosing of placement will lead to different brand attitudes.

\section{Product Placement}

There are three types of product placement: visual, spoken and usage (Russo, 2010). A visual style product placement product can be observed by its logo, brand name, trademark, or any appearance which can easily be recognized. Spoken product placement is when audio mentions a particular product or service. A usage product placement occurs with the combination of visual and spoken product placement. Usage product placement has both visual and spoken factors.

\section{Purchase Intention}

Scholars define purchase intention as a personal behavioral tendency. Another definition indicates purchase intention as the desire to buy a brand (Shabbir, Kirmani, Iqbal, \& Khan, 2009). When someone's purchase intention increased, it means that the probability for the individual to purchase increases (Schiffman \& Kanuk, 2007). Daneshvary and Schower (2000) believe that purchase intention is not only to describe the preference of the consumers but a relationship with demographics like age, sex, social class, and education. Purchase intention can also be defined as the decision of physical behavior, which indicates that a person's behavior is based on the product itself (Wang \& Yang, 2008). 


\section{Brand Attitude}

Attitude is the behaviour of observing a particular subject to make a judgment of whether have a preference on the subject or not (Filieri \& McLeay, 2014). Besides expressing positive and negative comments and feelings, the attitude also reflects the intention to act in agreement or disagreement (Lin, Wu, Liu, \& Lee, 2012). There are two discourses in advertising: direct or indirect (Chan, 2017). A direct or indirect advertisement leads the consumer into different brand attitudes which may influence their purchase intention and buying decision. Attitudes towards brands or brand attitudes are a key factor in measuring the value of the brand. Poudpongpaiboon and Arakvichanun (2014) define that attitude can be learned from the environment or people we always get along with; based on particular subjects, the process of learning has a prediction of its preference.

\section{Product Placement and Purchase Intention}

Purchase intention is a thought (Park, 2002). According to a research by Yao and Huang (2017) with a hypothesis that product placement marketing shows remarkable effects on purchase intention in a traditional industry. Gageler and van der Schee (2016) argued that product placement has a positive correlation with purchase intention, it has a positive influence on product placement which increases their positive purchase intention especially when it is with favourite celebrity even though they perceive it as unethical. Patton (2014) found that there is no relationship between product placement and respondent's intention to purchase but they are more likely to buy a prominent product in product placement with character. Audiences are more willing to purchase products with explicit placement rather than implicit (Lai, Lai, \& Chiang, 2015). Therefore, based on the above works of literature, a hypothesis is formed based on purchase intention:

- H1: There is a significant correlation between product placement in film and purchase intention.

\section{Product Placement and Brand Attitude}

Brand attitude is defined as the positive or negative recognition of a consumer towards a branded product or service (Dolbec \& Chebat, 2013). According to Nagar (2016) with the presence of consumer response towards brand placement in a movie, the researcher found that entertainment event is significantly predictive of an increase in the evaluation of brands placed in movies. Audiences generally have a favorable attitude towards those placed product on product placements as long as the product were not the product that will bring negative impact on human (Schmoll, Hafer, Hilt, \& Reilly, 2006). Males are more likely to accept cars and $3 \mathrm{C}$ products in a movie while females are more likely to accept food and beverage (Guido et al., 2010). Hence the hypothesis below is made:

- H2: There is a significant correlation between product placement in film and brand attitude.

\section{Purchase Intention After the Exposure of Product Placement}

A lot of evidence shows that product placement will affect purchase intention (Friedman \& Morton, 2002, as cited in Kuhn, Hume, \& Love, 2010). Srivastava (2014) researched product placement as an alternative strategy for a better brand recall than an advertisement. Although 
brand recall has no support in this research, changes were found in perception, purchase intention, emotional connection, and a recommendation to others from the interview. Nagar (2016) did an experiment study and it reveals that product placement created positive purchase intention. Hence the hypothesis below is made:

- H3: There is a significant difference in purchase intention after the exposure of product placement.

\section{Brand Attitude After the Exposure of Product Placement}

Product placement is a technique used by marketers to shake consumers' brand attitudes (Avery \& Ferraro, 2000). The study by Homer (2009) investigated the effects of repetition of product placement in television and movies and it provided evidence that repetition of obvious placement will lead to a negative impact on brand attitude. Obvious product placement might get rejected by and offenses the audiences which then leads to a more negative result (Hall, 2007). Hudders, Cauberghe, Panic, Faseur, T., \& Zimmerman (2012) found that brand attitude getting higher when the brand that being placed is prominent but only when participants identified the artist in a music video that being shown. Therefore, based on the above literature, a hypothesis is formed:

- H4: There is a significant difference in brand attitude after the exposure of product placement.

\section{METHODOLOGY}

A quantitative research approach was applied to this study. Experiments were applied to this research design, with the correlational relationship of experiments in this research. There are two groups conducted in this experimental research (control and treatment group), each group with 20 students. Two groups from UCSI University were chosen to participate in this experimental research.

\section{Instruments}

A questionnaire was drawn out based on previous studies, literature, and a published thesis, which related to the topic of the researcher. The questionnaire contained four sections which are demographic profile, product placement, purchase intention, and brand attitude (see Appendix A and Appendix B). Demographic profile was measured by nominal and others were measured by Likert scale. Descriptive statistics, Pearson correlation, and paired sample t-test were applied as the statistical analysis.

\section{Participants and Sampling}

The researcher used convenience sampling as a sampling method, UCSI University (Kuala Lumpur campus) has approximately 10,000 students (UCSI University, 2018). Students selected as respondents for this research were age ranges 18- to 30-year-old undergraduate students. Two groups were chosen to participate in this experimental research, each group with 20 students. Participants were selected based on inclusion and exclusion criteria. For inclusion criteria, two characteristics were included: who likes to watch films, spends at least 
an hour monthly on film. Besides, for exclusion criteria, those who are knowledgeable in product placement were not counted in.

\section{Data Analysis}

Pearson correlation coefficient was used to run SPSS. Information provided was key in on SPSS to analyse. In analysis, a correlation coefficient was used to calculate the strength and route of the different variables (Rumsey \& Unger, 2015). The value of $r$ all the time is between +1 and -1 . -1 represents perfect negative; +1 represents perfect positive and 0 represents no relationship (Rumsey \& Unger, 2015). Paired sample T-test was used to compares two variables (purchase intention and brand attitude) that are from the same individual (product placement) pretest and post-test have to be compared to determine the difference (SPSS Tutorial: Paired sample T-test, n.d.).

\section{Data Collection}

The type of data collection conducted in this research was a quantitative survey. Students at UCSI University (KL campus) were suitable in contributing to this research. The Control group $(n=20)$ was required to fill in the questionnaire without watching the selected movie; the treatment group $(n=20)$ was required to fill in the questionnaire before and after watching the selected movie - Jurassic World. During the survey session, both groups were placed in the same venue to get a more accurate result. All participants were given a 5-10 minutes duration to complete the survey questionnaire without informing them of the purpose of the survey. A total amount of 40 participants were mainly selected from Block B library, Block $\mathrm{A}$, and Block $\mathrm{C}$.

\section{Participants}

Based on Table 1, out of 40 respondents, there are 17 (42.5\%), male respondents, while female respondents have $23(57.5 \%)$. Most of the respondents are age between $22-26(55 \%)$ and $1(2.2 \%)$ of the respondents are age $27-30.19$ respondents $(47.5 \%)$ has less than RM1000 income possibility because most of the respondents are students; 11 respondents $(27.5 \%)$ has an income range between RM1001-RM2000; 9 respondents $(22.5 \%)$ has an income range between RM2001-RM3000, and 1 respondent (2.5\%) has more than RM3001 income.

Table 1: Distribution of Respondents According to Demographic Characteristics $(n=40)$

\begin{tabular}{|c|c|c|}
\hline Subject & Frequency & Percentage (\%) \\
\hline \multicolumn{3}{|l|}{ Age: } \\
\hline $18-21$ & 17 & 42.5 \\
\hline $22-26$ & 22 & 55.0 \\
\hline $27-30$ & 1 & 2.5 \\
\hline $31-35$ & 0 & 0 \\
\hline \multicolumn{3}{|l|}{ Gender: } \\
\hline Male & 17 & 42.5 \\
\hline Female & 23 & 57.5 \\
\hline
\end{tabular}




\begin{tabular}{lcc}
\hline Nationality: & & \\
Malaysian & 21 & 52.5 \\
Indonesian & 9 & 22.5 \\
Chinese & 10 & 25.0 \\
Income: & & \\
Below RM1000 & 19 & 47.5 \\
RM1001-RM2000 & 11 & 27.5 \\
RM2001-RM3000 & 9 & 22.5 \\
Above RM3001 & 1 & 2.5 \\
Time spend on watching films per week: & & \\
$<1$ & 4 & 10.0 \\
1-2 hour(s) & 12 & 30.0 \\
2-3 hours & 17 & 42.5 \\
$>4$ & 7 & 17.5 \\
\hline
\end{tabular}

\section{FINDINGS}

The relationship between product placement in film and purchase intention is explained in Table 2. According to Guilford's Rules of Thumb, it shows that there was a moderate positive correlation between the two variables $(r=0.564, n=40, p=0.000)$ which indicates a significant relationship between product placement in film and purchase intention $(p<0.05)$. This explained that product placement leads to a higher purchase intention, and product placement in the film does influence audiences' intention to purchase.

Table 2: Pearson Correlation between variable Product Placement in film and purchace purchase Intention $(n=40)$

\begin{tabular}{cccc} 
& & Purchase Intention & H1 \\
& R & Sig Value $(p)$ & \\
Product Placement & $0.564^{* *}$ & 0.00 (accepted) & Accepted \\
\hline
\end{tabular}

**. Correlation is significant at the 0.01 level (2-tailed)

The relationship between product placement in film and brand attitude was explained in Table 3. According to Guilford's Rules of Thumb, it shows that there was a moderate positive correlation between the two variables $(r=0.648, n=40, p=0.000)$ which indicated a significant relationship between product placement in film and brand attitude $(p<0.05)$. This explained that product placement leads to a higher brand attitude, and product placement in the film does influence audiences' attitudes toward the brand. 
Table 3: Pearson Correlation between variable Product Placement in film and Brand Attitude $(n=40)$

\begin{tabular}{|c|c|c|c|}
\hline & \multicolumn{2}{|c|}{ Purchase Intention } & $\mathrm{H} 2$ \\
\hline & $\mathbf{R}$ & Sig Value $(p)$ & \\
\hline Product Placement & $0.648^{* *}$ & 0.00 (accepted) & Accepted \\
\hline
\end{tabular}

** Correlation is significant at the 0.01 level (2-tailed)

A Paired Samples T-Test was applied to examine the variables between pre-and post-exposure of respondents to a movie with product placement. According to Table 4, the mean has 15.60 before the exposure of the movie and 20.95 after watching the movie, 5.35 was increased. With the significant value of $0.000(p<0.05)$, there is a moderate positive correlation between the two variables $(t=-8.335, n=20, p=0.000)$ which indicated there is a significant difference between product placement in film and purchase intention after being exposed to product placement.

Table 4: Paired T-Test: Purchase Intention before and after the exposure towards product placement in the movie - Jurassic World $(n=20)$

\begin{tabular}{ccccc} 
Exposure & Mean & T-Value & $\begin{array}{c}\text { Significant } \\
\text { Value }(p)\end{array}$ & H3 \\
Before & 15.60 & -8.335 & 0.000 & Accepted \\
After & 20.95 & & & \\
\hline
\end{tabular}

According to Table 5, the mean before the exposure of the movie is 19.95. The mean after the exposure of the movie is $25.05,5.10$ was increased. With a significant value of 0.000 $(\mathrm{P}<0.05)$, there is a moderate positive correlation between the two variables $(t=-3.435, n=$ $20, p=0.003$ ) which indicated there is a statistically significant difference between product placement in film and brand attitude. Hence this can be concluded that respondents have a positive attitude toward the product placed.

Table 5: Paired T-Test: Brand Attitude before and after the exposure towards product placement in the Jurassic World $(\mathrm{n}=20)$

\begin{tabular}{ccccc} 
Exposure & Mean & T Value & $\begin{array}{c}\text { Significant } \\
\text { Value (P) }\end{array}$ & H4 \\
Before & 19.95 & -3.435 & 0.003 & Accepted \\
After & 25.05 & & & \\
\hline
\end{tabular}

\section{DISCUSSION}

This study was aimed specifically at the relationship between product placement, purchase intention, and brand attitude among college students. The data was analysed by Pearson Correlation and Paired sample t-test. All proposed hypotheses were fully supported, and the main findings are discussed. 
For H1, it was hypothesised that there would be a significant correlation between product placement in film and purchase intention. This study pointed out the correlation between product placement and purchase intention. Lai and colleagues (2015) stated that explicit placement has a higher mean than implicit placement. Omarjee and Chiliya (2014) tested the relationship between brand recognition and purchase intention in music videos which significant was less than $\mathrm{P}<0.05$. Yao and Huang (2017) found placement marketing shows remarkable effects on purchase intention.

On the other hand, according to Patton (2014), no correlation was found between product placement and purchase intention $(r=.07, p=0.425)$. This was because most of the respondents still believed that they were more influenced to purchase the product they saw in a commercial advertisement. Besides, the researcher did not mention any brand name or a specific product in the questionnaire. In the research of the discussed topic, a specific product Coca-Cola was mentioned with the same hypothesis as Patton, a significant relationship was found in the current research.

For H2, it was postulated that product placement in film correlates significantly with brand attitude. The result found in this study was similar to that of Kit and P'ng (2014) They found that respondents were more in favour of a brand being placed more subtlety. It is also similar to the result by Balasubramanian, Patwardhan, Pillai, and Coker (2014) They stated that the attitude toward product placement has a positive influence on the brand. Kwon (2012) shows that the more the audience watch television shows the more positive attitude they will have toward the product placement. The hypothesis being supported with Correlation Analysis $(r=0.290, p=0.01)$.

However, Chan and colleagues' (2016) research result was in contrast with the result of this study. Their study was conducted in the relationship between respondents' cognitive influence on their brand, and the attitude towards the placed brand before, and after, exposure to selected videos. The results show a statistically significant negative association between respondents' cognitive and attitude towards the placed brand $(p=0.12, p<0.05)$ because participants' brand attitude towards the placed brand gets more resistantly once they noticed the appearance of the brand. Respondents from both researchers were from a similar age range, but the result did not show the same, this can be inferred that different results will happen even in a similar age range.

For $\mathrm{H} 3$, it was hypothesised that there is a significant difference in purchase intention after the exposure of product placement. This study pointed to the purchase intention before and after the exposure towards product placement. Kyrkjeeide and Lervik (2015) research result found a positive significant change in purchase intention for the weak brands after respondents were exposed to subtle product placements.

Chan (2012) examined that there is a negative relationship between product placement and purchase intention, but this hypothesis has no evidence to support which means that there is a positive relationship between these two variables. A similar result was found from research by Reis (2013). She stated that children who are exposed to commercial media with product placement have lower purchase intention than children who are not exposed.

However, this is contradicting with the result by Fichman (2015) that gender will influence the purchase intention on product placement. To get a high-quality response to this hypothesis, there is an equal of female and male respondents which $48.7 \%$ of female and $51.3 \%$ of male. The significant value between females and purchase intention on product 
placement has 0.695 and 0.351 for males $(\mathrm{P}<0.05)$. Although there is equality amount of gender, both females and males did not show support because the chosen brand was a processed meats brand that has no interest to most of the participants. The similarity found from the research, correlated to the current research, both female and male respondents have $57.5 \%$ and $42.5 \%$, but the hypothesis "there is a significant difference on purchase intention after the exposure of product placement" was being supported. There was a slight difference between the two pieces of research in which Fichman focused his research on science which is visuospatial abilities, this is an individual's capacity to identify visual perception and association among ("Visuospatial Ability," 2017); the current researcher focused her research on an advertisement.

For H4, it was postulated that there is a significant difference in brand attitude after the exposure of product placement. This study pointed to the brand attitude before and after the exposure towards product placement. "Placement marketing presents significant effects on product attitude" was found supported by Yao and Huang (2017) with a significant value of $0.000(p<0.05)$. Cholinski $(2012)$ research result was similar to the result of this study. He has a hypothesis of when audiences were exposed to prominent placement, they will have a more positive attitude towards the placed brand. The hypothesis was being supported. Besides, Ruggieri and Boca (2013) found that respondents who were exposed to the video treatment have a positive attitude with mere placement.

It is inconsistent with the study of Dietrich (2016) which he argued that there is no change in the attitude of respondents towards the product placement of the "Febreze" brand. The hypothesis was supported. Most of the respondents have only one point and two points of willingness to use it because they noticed that it was a product placement. The result shows a difference from the current research, with the similar item "I like Coca-Cola I watched in the film", has only $27.5 \%$ of respondents answered strongly disagree and disagree with this item. Respondents of the research are mostly from the United States (U.S). In the United States, product placement has been commonly used, \$3,700,000 had been spent on product placement in 2008 and the cost is expected to increase (Williams, Petrosky, Hernandez, \& Page, 2011). The possible reason being people staying in the U.S. have common knowledge of product placement. Due to this, they may have had a more negative attitude on product placement.

\section{IMPLICATIONS}

Theoretical and practical implications were found in this study. In the perspective of theoretical implication, the study helps to further prove that the two theories applied are applicable to contribute. Both theories were applied and significance was found, which supported the applicability of the Hidden Message and the Character-Product Interaction (CPI) for undergraduate students in UCSI University. For practical implication, this study suggests marketers apply the product placement strategy in a film to increase the purchase intention and positive brand attitude of audiences. The research could serve to provide marketers/advertisers a deeper understanding of product placement in the current market situation, specifically in Malaysia. 


\section{LIMITATIONS}

The research has its limitation where it is conducted within a small population in which only 40 respondents among UCSI University (KL Campus). It is suggested to research a similar topic covering more age groups and a larger sampling size. Besides, time is also a limitation in this research since respondents were required to watch a two-hour movie. Future researchers are suggested to conduct their experiment with a longer duration. Another limitation of this study was that the researcher selected only one product from a movie for the treatment group in the experiment. Results were only focused on the particular product without any comparison with other products. This can only represent the success of product placement on the category of the product or the genre of the movie.

\section{CONCLUSION}

Purchase intention is found to has a correlation and significant relationship with the product placement among students at UCSI University. They have positive purchase intention towards product placement but they will not consider purchasing the Coca-Cola product in the long term.

Additionally, brand attitude is found to have a correlation and significant relationship with the product placement in the film despite a low preference towards the product in the selected film. Furthermore, a significant difference was found in purchase intention after the exposure. Students at UCSI University are likely to purchase the product in short term instead of the long term. However, a significant difference was found in brand attitude after the exposure by the mean increased. Respondents have a significant positive change of brand attitude with the appearance of Coca-Cola in the movie but it does not mean they will not consider buying other brands.

In short, UCSI University students generally have positive purchase intention and brand attitude on product placement in a film no matter before or after the exposure to the selected movie Jurassic World. The exposure of a product in a film positively improves their brand attitude towards the brand of the product placed, and so does their purchase intention. However, product placement is not the only factor influencing the audience's brand attitude and purchase intention.

\section{REFERENCES}

Avery, R. J. \& Ferraro, R. (2000). Verisimilitude or advertising? Brand appearances on primetime television. Journal of Consumer Affairs, 34(2), 217-244.

Balasubramanian, S. K., Patwardhan, H., Pillai, D., \& Coker, K. K. (2014). Modeling attitude constructs in movie product placements. Journal of Product $\mathcal{E}$ Brand Management, 23(7), 516-531.

Bhasin, H. (2017, December 24). Advertising theory. Marketing91. https://www.marketing91. com/advertising-theory/

Boerman, S. C., Van Reijmersdal, E. A., \& Neijens, P. C. (2015). Using eye tracking to understand the effects of brand placement disclosure types in television programs. Journal of Advertising, 44(3), 196-207. 
CBC Radio. (2015, August 25). Show me the money: The world of product placement. CBC. http://www.cbc.ca/radio/undertheinfluence/show-me-the-money-the-world-of-productplacement-1.3046933

Chan, F. F. Y. (2012). Product placement and its effectiveness: A systematic review and propositions for future research. The Marketing Review, 12(1), 39-60.

Chan, F. F. Y., Lowe, B., \& Petrovici, D. (2016). Processing of product placements and brand persuasiveness. Marketing Intelligence E Planning, 34(3), 355-375.

Chan, Y. W. D. (2017). The Effectiveness of soft-sell and hard-sell panasonic flyerson consumer attitude [Unpublished bachelor's thesis]. UCSI University.

Cholinski, A. (2012). The effectiveness of product placement: A field quasi-experiment. International Journal of Marketing Studies, 4(5), 14.

Chung, S. W., \& Szymanski, K. (1997). Effects of brand name exposure on brand choices: An implicit memory perspective. Advances in Consumer Research, 24, 288-294.

Daneshvary, R., \& Schwer, K. (2000). The association endorsement and consumers' intention to purchase. Journal of Consumer Marketing, 17, 203-213.

Dietrich, F. (2016). Effectiveness of product placement in TV Shows [Unpublished doctoral dissertation]. Laureate International Universities, Baltimore, Maryland, United States.

Dodds, W. B., Monroe, K. B., Grewal, D. (1991). Effects of price, brand, and store information on buyers' product evaluation. Journal of Marketing Research, 28(3), 307-319.

Dolbec, P. Y., \& Chebat, J. C. (2013). The impact of a flagship vs. a brand store on brand attitude, brand attachment and brand equity. Journal of Retailing, 89(4), 460-466.

Falkow, S. (2010). PR trends 2010: Branded content. The Proactive Report, 30. Retrieved from http://proactivereport.com/pr-trends-2010-branded-content/

Fichman, T. (2015). Hunting and gathering for product placement in movies: A visuopatial approach [Unpublished doctoral dissertation]. The University of Guelph, Ontario, Canada.

Filieri, R., \& McLeay, F. (2014). E-WOM and accommodation: An analysis of the factors that influence travelers' adoption of information from online reviews. Journal of Travel Research, 53(1), 44-57.

Gageler, L., \& van der Schee, J. (2016). Product placement on social media: A study on how Generation Y's brand perception and purchase intention are influenced (Dissertation). http:// urn.kb.se/resolve?urn=urn:nbn:se:hj:diva-30374

Gillespie, B., Joireman, J., \& Muehling, D. D. (2012). The moderating effect of ego depletion on viewer brand recognition and brand attitudes following exposure to subtle versus blatant product placements in television programs. Journal of Advertising, 41(2), 55-66.

Guido, G., Peluso, A. M., Tedeschi, P., Nicole, C., Lauretti, C., \& Caciula, A. (2010). Acceptance of product placement in Italy: Effects of personality and product/consumer interactions. International Journal of Marketing Studies, 2(2), 37-46.

Hall, E. (2007). Product placement faces wary welcome in Britain. Advertising Age, 78(2), 27. Homer, P. M. (2009). Product placements. Journal of Advertising, 38(3), 21-32.

Hudders, L., Cauberghe, V., Panic, K., Faseur, T., \& Zimmerman, E. (2012). Brand placement in music videos: the effect of brand prominence and artist connectedness on brand recall and brand attitude. In $11^{\text {th }}$ International Conference on Research in Advertising (ICORIA 2012): The changnig rolse of avderitsing, Stockholm, Sweden. 
Kamleitner, B., \& Khair Jyote, A. (2013). How using versus showing interaction between characters and products boosts product placement effectiveness. International Journal of Advertising, 32(4), 633-653.

Kit, L. C., \&; P’ng, E. L. Q. (2014). The effectiveness of product placement: The influence of product placement towards consumer behavior of the millennial generation. International Journal of Social Science and Humanity, 4 (2), 138-142. https://doi.org/ 10.7763/IJSSH.2014. V4.334.

Kramolis, J., \& Drabkova, M. (2012). Types, forms and major product categories of product placement in the Czech Republic. Journal of Eastern Europe Research in Business E Economics, 2012, 1-11.

Kuhn, K. A. L., Hume, M., \& Love, A. (2010). Examining the covert nature of product placement: Implications for public policy. Journal of Promotion Management, 16(1-2), 59-79.

Kumar, S. (2017). Influence of product placements in films and television on consumers brand awareness. Archives of Business Research, 5(2), 163-179

Kwon, E. S. (2012). Exploring consumer's attitudes and behavior toward product placement in television shows [Unpublished doctoral dissertation]. Syracuse University.

Kyrkjeeide, E., \& Lervik, V. R. (2015). Product placement in the Norwegian market-Is product placement a valid tool for marketers in Norway? [Unpublished master's thesis]. Norwegian School of Economics, Norway.

Lai, Y. F., Lai, C. Y., \& Chiang, H. S. (2015). The advertising effectiveness of advertising message and product placement on video advertisement. Recent Researches in Applied Computer Science, 113, 112-121.

Lin, J., Wu, C., Liu, W., \& Lee, C. (2012). Behavioral intentions toward afforestation and carbon reduction by the Taiwanese public. Forest Policy and Economics, 14(1), 119-126.

Mitchell, A. A., \& Olson, J. C. (1988). Are product attribute beliefs the only mediator of advertising effects on brand attitude?, Journal of Marketing Research, 18 (3), 318-332.

Nagar, K. (2016). Consumer response to brand placement in movies: investigating the brandevent fit. Vikalpa, 41(2), 149-167.

Newell, J., Salmon, C. T., \& Chang, S. (2006). The hidden history of product placement. Journal of Broadcasting E Electronic Media, 50(4), 575-594.

Omarjee, L. \& Chiliya, N. (2014). The effectiveness of product placement in music videos: a study on the promotion strategies for brands and products to target the $\mathrm{Y}$ generation in Johannesburg. Mediterranean Journal of Social Sciences, 5 (20), 2095- 2118. https//doi. org/10.5901/mjss.2014.v5n20p2095.

Oxford Economics. (2013). The economic contribution of the film and television industries in Malaysia. https://www.mpa-i.org/wp-content/uploads/2014/08/Msia_2013.pdf

Park, C. (2002, July). A model on the online buying intention with consumer characteristics and product type. In Proceedings of Ausweb, $8^{\text {th }}$ Australian World Wide Web Conference, Queensland, Australia.

Patton, D. (2014). A study of the effect of product placement in television shows and its influence on consumer behavior [Unpublished bachelor's thesis]. California Polytechnic State University.

Poudpongpaiboon, S. \& Arakvichanun, N. (2014). Insight capturing Thai Gen Y consumers. https://www.scbeic.com/en/detail/file/.../Insight_Eng_GenY_2014.pdf 
Reis, M. C. C. (2013). How can commercial media literacy change the influence of product placement on children [Unpublished doctoral's dissertation). Nova School of Business and Economics, Carcavelos, Portugal.

Ruggieri, S., \& Boca, S. (2013). At the roots of product placement: The mere exposure effect. Europe's Journal of Psychology, 9(2), 246-258.

Rumsey, D. J., \& Unger, D. (2015). U Can: statistics for dummies. London: John Wiley \& Sons. Russo, M. (2010, May 6). Product placement. Retrieved May 28, 2018, from http://commfaculty. fullerton.edu/kjupak/Courses/452/StudentWork_f02/Product Placement.doc

Schiffman, L.G., Kanuk, L.L. (2007). Consumer Behavior (9 $9^{\text {th }}$ ed.). New Jersey: Prentice-Hall Inc.

Schmoll, N. M., Hafer, J., Hilt, M., \& Reilly, H. (2006). Baby boomers' attitudes towards product placements. Journal of Current Issues \& Research in Advertising, 28 (2), 33-53.

Shabbir, M. S., Kirmani, M. S., Iqbal, J., \& Khan, B. (2009). COO and brand name's affect on consumer behavior and purchase intention in Pakistan. Interdisciplinary Journal of Contemporary Research in Business, 1 (3), 84-95.

Srivastava, R. K. (2015). Product placement by global brands as an alternative strategy: Is it worth in emerging market? Journal of Strategic Marketing, 23 (2), 141-156.

SPSS Tutorials: Paired Samples t Test. (n.d.). Retrieved June 3, 2018, from https:/libguides. library.kent.edu/SPSS/PairedSamplestTest

Visuospatial Ability. (2017, September 6). NeuRA. Retrieved July 9, 2018, from https://library. neura.edu.au/browse-library/signs-and-symptoms/cognition/visuospatial-ability/

Van der Heijden, H., Verhagen, T., \& Creemers, M. (2003). Understanding online purchase intentions: contributions from technology and trust perspectives. European Journal of Information Systems, 12(1), 41-48.

Wang, X., \& Yang, Z. (2008). Does country-of-origin matter in the relationship between brand personality and purchase intention in emerging economies? Evidence from China's auto industry. International Marketing Review, 25 (4), 458-474.

Williams, K., Petrosky, A., Hernandez, E., \& Page, Jr. R. (2011). Product placement effectiveness: revisited and renewed. Journal of Management and Marketing Research, 7, 1-24.

Wu, S. I., \& Wang, W. H. (2014). Impact of CSR perception on brand image, brand attitude and buying willingness: a study of a global café. International JournalofMarketing Studies, 6(6), 43-56.

Yao, C. \& Huang, P. (2017). Effects of placement marketing on product attitude and purchase intention in traditional industry. Eurasia Journal of Mathematics, Science and Technology Education, 13 (12), 8305-8311.

Yousif, R. O. (2012). Factors affecting consumer attitudes towards mobile marketing. Journal of Database Marketing \& Customer Strategy Management, 19 (3), 147-162. 